Membangun Mental Positif Buruh Perempuan Korban PHK Pandemi Covid 19 di Kawasan Industri Pulogadung, Jakarta Timur Melda Rumia Rosmery Simorangkir, Hendrikus Male, Mesta Limbong, \& Anne Grice Issabella

Pemberdayaan Panti Asuhan Berkah Palangka Raya sebagai Basis Usaha Olahan Ikan di Kota Palangka Raya Kalimantan Tengah Siti Zubaidah, Norhayani, \& Sri Endang Agustina Rahayuningsih

Pendidikan Kesehatan pada Ibu Hamil tentang Anemia menggunakan Media Video di Kota Palangka Raya

Oktaviani \& Heti Ira Ayue

Pemanfaatan Lahan Pekarangan di Sekolah Sungai Ciliwung Jakarta untuk Tanaman Buah-Buahan Hinijati Widjaja, Rini Fitri, Reza Fauzi, \& Harmaini

Pelatihan Pembuatan Hand Sanitizer yang Lembut di Kulit dalam Pencegahan Covid-19 di Kalangan Siswa SMA Rizka Novia Atmadani

Pemberdayaan Masyarakat dan Mahasiswa dalam Mewujudkan Desa Mandiri melalui Pemanfaatan Lahan dan Sampah di Kecamatan Tanjung Palas Utara, Kabupaten Bulungan

Arif Rohman, Dewi Nurvianti, \& Sapriani

Model Desain Apotik Hidup bagi Keberlanjutan Pemanfaatan Pengolahan Sampah Organik Rumah Tangga di Desa Ciangsana, Kabupaten Bogor

Silia Yuslim, Etty Indrawati, Dwi Indrawati, \& Olivia Seanders

\title{
Makanan Sehat untuk Kesehatan Otak
}

Agnescia Clarissa Sera \& Prisilia Oktaviyani

Peningkatan Pengetahuan Perilaku Hidup Bersih dan Sehat Mental Masyarakat Kalurahan Timbulharjo, Sewon, Bantul di Era New Reality Covid-19

Khoiriyah Isni, Ardarina Delfiona Kekasi, Nur Safani Indriani, \& Juwita Sari

Pembinaan Desain Produk Amplang Ikan sebagai Alternatif Usaha Rumahan bagi Ibu-Ibu PKK Desa Terantang, Barito Kuala Rizky Nastiti, Norbaiti, Masithah Akbar, \& Lydia Goenadhi

Peningkatan Pengetahuan tentang Kanker Serviks pada Kader sebagai Upaya Peningkatan Cakupan Deteksi Dini Kanker Serviks Kartika Adyani, Emi Sutrisminah, \& Hanifatur Rosyidah

Racikan Minuman Jamur Tiram (Pleurotus ostratus) sebagai Peningkat Kesehatan Tubuh

Uce Lestari, Damris Muhammad, Ade Adriadi, \& Minarni

Pemberdayaan Masyarakat dalam Pembuatan Lulur Tradisional dari Beras dan Kunyit di Kecamatan Cempaka Banjarbaru Helmina Wati, Rahmi Hidayati, Eny Hastuti, \& Nurul Mardiati

Pemberdayaan Masyarakat melalui Edukasi Cara Pembuatan Pangan Olahan yang Baik, Bahan Tambahan Pangan, dan Kemasan Pangan untuk Penguatan Jaminan Keamanan pada Pelaku UMKM Bidang Makanan di Balikpapan

Iuni Ekowati, Rosita Handayani, Dewo Melani Hariyadi, Mohammad Rizki Fadhil Pratama, Putri Hamidah Khairunnisa, Melanny Ika Sulistyowaty, Rossa Auli Tasha, Imamatin Nufus Melania, Ersanda Nurma Praditapuspa, Muhamad Ilham Royyan Nafi'

Edukasi Bounding Attachment dalam Upaya Menciptakan Hubungan Ibu dan Anak setelah Melahirkan Dewi Susilawati, Nur Fadjri Nilakesuma, Novria Hesti, Yeni Gea, Nur Salsabila W S, Ramadhany Hafsah Qonita, \& Armein Syahid

Pemberdayaan Masyarakat dalam Pemanfaatan Kalakai (Stenochlaena palustris (Burm. F) Bedd.) sebagai Antioksidan Alami pada Kelompok Ibu-Ibu PKK di Kelurahan Palam, Kecamatan Cempaka, Banjarbaru

Ratna Restapaty, Dyera Forestryana, Hafiz Ramadhan, Revita Saputri, Satrio Wibowo Rahmatullah, \& Rahmayanti Fitriah 




Jurnal Ilmiah Pengabdian Kepada Masyarakat

Volume 6, Issue 6, October 2021

Membangun Mental Positif Buruh Perempuan Korban PHK Pandemi Covid 19 di Kawasan Industri Pulogadung, Jakarta Timur Melda Rumia Rosmery Simorangkir, Hendrikus Male, Mesta Limbong, \& Anne Grice Issabella

Pemberdayaan Panti Asuhan Berkah Palangka Raya sebagai Basis Usaha Olahan Ikan di Kota Palangka Raya Kalimantan Tengah

Siti Zubaidah, Norhayani, \& Sri Endang Agustina Rahayuningsih

Pendidikan Kesehatan pada Ibu Hamil tentang Anemia menggunakan Media Video di Kota Palangka Raya

Oktaviani \& Heti Ira Ayue

Pemanfaatan Lahan Pekarangan di Sekolah Sungai Ciliwung Jakarta untuk Tanaman Buah-Buahan

Hinijati Widjaja, Rini Fitri, Reza Fauzi, \& Harmaini

Pelatihan Pembuatan Hand Sanitizer yang Lembut di Kulit dalam Pencegahan Covid-19 di Kalangan Siswa SMA

Rizka Novia Atmadani

Pemberdayaan Masyarakat dan Mahasiswa dalam Mewujudkan Desa Mandiri melalui Pemanfaatan Lahan dan Sampah di Kecamatan Tanjung Palas Utara, Kabupaten Bulungan

Arif Rohman, Dewi Nurvianti, \& Sapriani

Model Desain Apotik Hidup bagi Keberlanjutan Pemanfaatan Pengolahan Sampah Organik Rumah Tangga di Desa Ciangsana, Kabupaten Bogor

Silia Yuslim, Etty Indrawati, Dwi Indrawati, \& Olivia Seanders

Makanan Sehat untuk Kesehatan Otak

Agnescia Clarissa Sera \& Prisilia Oktaviyani

Peningkatan Pengetahuan Perilaku Hidup Bersih dan Sehat Mental Masyarakat Kalurahan Timbulharjo, Sewon, Bantul di Era New Reality Covid-19

Khoiriyah Isni, Ardarina Delfiona Kekasi, Nur Safani Indriani, \& Juwita Sari

$598-603$

Pembinaan Desain Produk Amplang Ikan sebagai Alternatif Usaha Rumahan bagi Ibu-Ibu PKK Desa Terantang, Barito Kuala Rizky Nastiti, Norbaiti, Masithah Akbar, \& Lydia Goenadhi

Peningkatan Pengetahuan tentang Kanker Serviks pada Kader sebagai Upaya Peningkatan Cakupan Deteksi Dini Kanker Serviks Kartika Adyani, Emi Sutrisminah, \& Hanifatur Rosyidah

Racikan Minuman Jamur Tiram (Pleurotus ostratus) sebagai Peningkat Kesehatan Tubuh

Uce Lestari, Damris Muhammad, Ade Adriadi, E Minarni

Pemberdayaan Masyarakat dalam Pembuatan Lulur Tradisional dari Beras dan Kunyit di Kecamatan Cempaka Banjarbaru Helmina Wati, Rahmi Hidayati, Eny Hastuti, \& Nurul Mardiat

Pemberdayaan Masyarakat melalui Edukasi Cara Pembuatan Pangan Olahan yang Baik, Bahan Tambahan Pangan, dan Kemasan Pangan untuk Penguatan Jaminan Keamanan pada Pelaku UMKM Bidang Makanan di Balikpapan

Juni Ekowati, Rosita Handayani, Dewi Melani Hariyadi, Mohammad Rizki Fadhil Pratama, Putri Hamidah Khairunnisa, Melanny Ika Sulistyowaty, et al.

Edukasi Bounding Attachment dalam Upaya Menciptakan Hubungan Ibu dan Anak setelah Melahirkan

Dewi Susilawati, Nur Fadjri Nilakesuma, Novria Hesti, Yeni Gea, Nur Salsabila W S, Ramadhany Hafsah Qonita, \& Armein Syahid

Pemberdayaan Masyarakat dalam Pemanfaatan Kalakai (Stenochlaena palustris (Burm. F) Bedd.) sebagai Antioksidan Alami pada Kelompok Ibu-Ibu PKK di Kelurahan Palam, Kecamatan Cempaka, Banjarbaru

Ratna Restapaty, Dyera Forestryana, Hafiz Ramadhan, Revita Saputri, Satrio Wibowo Rahmatullah, E Rahmayanti Fitriah 


\title{
PengabdianMu: \\ Jurnal Ilmiah Pengabdian kepada Masyarakat
}

\author{
Publisher: \\ Institute for Research and Community Services \\ Universitas Muhammadiyah Palangkaraya \\ Editor-in-Chief: \\ Dr. Nurul Hikmah Kartini, S.Si., M.Pd.
}

Associate Editors:

apt. Mohammad Rizki Fadhil Pratama, S.Farm., M.Si.

Eko Cahyo Utomo, S.Pd.

Gusti Iqbal Tawaqal, M.T.

Dr. Arta Moro Sundaja, M.M.

Prof. Dr. Hamdanah, M.Ag.

Dr. Laksminarti, S.H., M.H.

Dr. Achmadi, M.H.

Wiwit Probowati, M.Biotech.

Prof. Dr. Ir. Sujono, M.Kes.

Dr. Yoppy Wahyu Purnomo, M.Pd.

Dr. Rita Rahmaniati, M.Pd.

Dr. Muhammad Rusydi, M.Ag.

Dr. Iin Nurbudiyani, M.Pd.

Dr. Sanawiah, S.Ag., M.H.

Dr. Yahya Mof, M.Pd.

Dr. Sugiharto, M.Pd.

Dr. Vina Salviana Darvina S., M.Si

Dr. Saijo, M.P.

Novrianti, M.T.

\section{Reviewers:}

(Binus University)

(Institut Agama Islam Negeri Palangka Raya)

(Universitas Muhammadiyah Palangkaraya)

(Universitas Muhammadiyah Palangkaraya)

(Universitas Aisyiyah Yogyakarta)

(Universitas Muhammadiyah Malang)

(Universitas Negeri Yogyakarta)

(Universitas Muhammadiyah Palangkaraya)

(Universitas Islam Negeri Antasari)

(Universitas Muhammadiyah Palangkaraya)

(Universitas Muhammadiyah Palangkaraya)

(Universitas Islam Negeri Antasari Banjarmasin)

(Universitas Palangka Raya)

(Universitas Muhammadiyah Malang)

(Universitas Muhammadiyah Palangkaraya)

(Universitas Muhammadiyah Palangkaraya)

\section{Circulation \& IT:}

Sutami, M.Kom.

\section{Address:}

Institute for Research and Community Services

Universitas Muhammadiyah Palangkaraya, Campus I building B ground floor

RTA Milono St. Km.1,5 Palangka Raya 73111 Indonesia

Phone/Fax. (0536) 3222184; email : pengabdianmu@umpr.ac.id website : http://journal.umpalangkaraya.ac.id/index.php/pengabdianmu 


\section{PREFACE \\ EDITOR-IN-CHIEF}

Assalamu'alaikum Wr. Wb.

Dear reader, now PengabdianMu: Jurnal Ilmiah Pengabdian kepada Masyarakat re-published on Volume 6 Issue 6 October 2021. This edition marks a change in publication frequency from four times to six times a year.

The publication of PengabdianMu: Jurnal Ilmiah Pengabdian kepada Masyarakat certainly participate in disseminating the results of community services in science and technology development conducted by lecturers and researchers especially from UM Palangkaraya and other universities.

This edition contains 16 articles consisting of Education, Social and Political, Agriculture, and Health Science topics. Editorial boards are fully aware that there are still room for improvement in this edition, hence with all humility willing to accept constructive suggestions and feedback for improvements to the publication for the next editions.

The editorial board would like to thank the University, all editors and reviewers, and contributors of the scientific articles who have provided the repetoire in this issue. We hope that all parties, especially the contributors of the articles, could re-participate for the success of the publication in the next edition on December 2021.

Wassalamu'alaikum Wr. Wb.

Palangka Raya, October 2021

Editor-in-Chief,

signed

Dr. Nurul Hikmah Kartini, S.Si., M.Pd. 


\section{AUTHOR GUIDELINES}

1. Writing is the result of community services in the field but not limited to education, social, political, agricultural, forestry, islamic studies, engineering, and health sciences which has never been published.

2. The manuscript is written in Indonesian or English with Book Antiqua font $10 \mathrm{pt}, 2$ (two) column, density 1.5 spaces, on A4 paper with a top-down margins of $3.5 \mathrm{~cm}$ and right-left margins $2 \mathrm{~cm}$.

3. The manuscript is typed with MS-Word program using the provided template and saved in .doc or .docx format.

4. The manuscript is typed strcitly with the following rules:

a. Title, Short and clear, written in Indonesian and English. The title length does not exceed 20 words.

b. Authors, listed without mention of title or degree, under the name including the affiliation and complete address, and email of the corresponding author.

c. Abstract, written in Indonesian and English which is a summary of the article. Abstract are created in one paragraph and a maximum of 250 words with Book Antiqua font 9 pt, single column, and space 1.

d. Introduction, background, reasons for the importance of underlying research or hypotheses, general approaches and objectives of research and relevant literature review. The number of paragraphs in not restricted but the contents must be includes background, objectives, positions on previous researchs, as well as novelty of the research. Little theoretical basis which in directly related to the contents of the article could be included without sub-chapters required. Citation of more than one author written in et al.

e. Methodology, Research method consists of 2 sub-chapters including instruments and materials, and methods. If data analysis is specific, or the way of analysis is novel, then data analysis sub-chapter could be added. The sub-chapters are written without numbering or bullet.

f. Results and Discussion, at least contains three subjects (1) description of results, (2) interpretation or explanation of results, and (3) comparative of results with previous studies results. If the subchapters very length could be made sub-sub-chapters with arabic numbering. Description of the results can be in the form of tables and figures with serial number (Table uses a sequence of roman numerals and placed at the top, while figures using arabic numeric sequence and placed in the below).

g. Conclusion, made in a single paragraph without the citation contains the final conclusion and suggestions for advanced research.

h. References, a list of recently selected topics is published last 5 years (minimum $75 \%$ of at least 10 references). Bibliography written in alphabetical order chronologically without serial number (Harvard System) and suggested using a reference management application such as End Note, Mendelley, Zotero, and other applications.

5. The typed manuscripts submitted via OJS PengabdianMu: Jurnal Ilmiah Pengabdian kepada Masyarakat with the url http://journal.umpalangkaraya.ac.id/index.php/pengabdianmu.

6. Authors whose manuscripts are published, subject to Publication Fee of Rp. 600.000,- as per the cost of printing and may change at anytime according to the printing prices.

7. Authors will get 1 printed copy of issue and the article also published on e-journal of UM Palangkaraya at the website http://journal.umpalangkaraya.ac.id/index.php/pengabdianmu. 


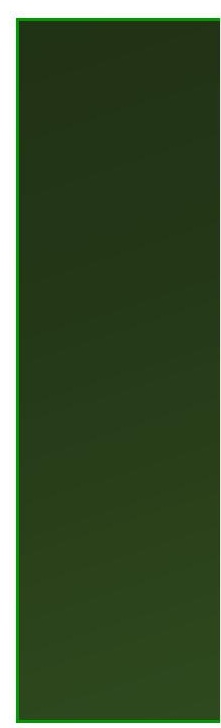

